\title{
THE EFFECTS OF CRUDE RECOMBINANT VIRAL PROTEIN VACCINES AGAINST GROUPER SLEEPY DISEASE IRIDOVIRUS (GSDIV) ON HUMPBACK GROUPER (Cromileptes altivelis)
}

\author{
Ketut Mahardika and Indah Mastuti \\ Institute for Mariculture Research and Development \\ (Received 29 September 2015; Final revised 4 November 2015; Accepted 10 November 2015)
}

\begin{abstract}
Infection of Megalocytivirus cause serious mass mortality in marine fish in South East Asian countries. The aim of this study was to produce recombinant of GSDIV capsid protein and its protection to humpback grouper Cromileptes altivelis against grouper sleepy disease iridovirus (GSDIV). A major capsid protein (MCP) was selected for use as a crude subunit vaccines. This gene target (MCP) was inserted to the protein expression system vector of pET SUMO and cloned in cells bacteria Escherichia coli strain BL-21. The MCP was succeded to be induced using $1 \mathrm{mM}$ of IPTG. Results of protein analysis using MALDI TOF-TOF indicated that the MCP has measurement of $49.566 \mathrm{kDa}$ with PI index of 6.00, and contained 453 amino acids. BLAST homology analysis exhibited that the amino acid sequence of the MCP showed high similarity with MCP of Red Sea Bream Iridovirus (RSIV). E. coli expressing MCP protein was inactivated using $0.03 \%$ formalin overnight and washed using PBS. The inactivated $E$. coli as a crude subunit vaccine was then injected intramuscularly to humpback grouper juveniles. Subsequently, the juveniles were challenged tested with GSDIV. The juveniles vaccinated with the MCP recombinant bacteria showed significantly higher survival rates than control those vaccinated with PBS. Thus, the MCP fusion protein is considered as a potential vaccine against GSDIV infections in grouper.
\end{abstract}

KEYWORDS: humpback grouper, GSDIV, protein recombinant, vaccine

\section{INTRODUCTION}

In Indonesia, Megalocytivirus have been reported to infect and caused mass mortality in marine fish such as orange-spotted grouper Epinephelus coioides (Koesharyani et al., 2001; Mahardika et al., 2001; 2003), humpback grouper Cromileptes altivelis (Mahardika et al., 2004), tiger grouper E. fuscoguttatus, malabar grouper E. polyphekadion, coral trout grouper Plectropomus indicus (Mahardika et al., 2009b), sea bass Lates calcarifer (Mahardika \& Mastuti, 2010), and cobia Rachycentron canadum (Mahardika, personal communication). Recently, this disease is supposed to cause "drop scale disease" in barramundi in Batam island (Sunarto, personal communication). Megalocytivirus are also reported to infect freshwater fish such as dwarf gourami Colisa lalia, African lampeye Aplocheilichthys normani cultivated in Sumatra and exported to Japan via Singapore (Sudthongkong et al., 2002a), gourami Osphronemus gourami and tilapia Osteochillus hasselti (Koesharyani, personal communication).

\# Correspondence: Institute for Mariculture Research and Development. Jl. Br. Gondol, Kec. Gerokgak, Kab. Buleleng Kotak Pos 140, Singaraja-Bali 81101, Indonesia.

Phone: + (0362) 92272

E-mail: info.gondol@gmail.com
An effective and efficient drug for treatment of viral diseases has not been found. Antibiotics and vitamins were used to prevent secondary infections and boost the general immune system of fish. Furthermore, addition of omega interferon and liquid filtration of the spleen from diseased fish on RSIV pure virus (in vitro) has not been able to inhibit the proliferation of the virus in cells (Mahardika \& Miyazaki, 2009). Therefore, an early prevention using a specific vaccine for the Megalocytivirus disease is required. Prevention of Megalocytivirus infections has been successfully carried out by administration of inactivated vaccine and DNA-RSIV vaccine (Nakajima et al., 1997; 1999; Caipang et al., 2006). Vaccination has also been successfully performed on humpback grouper in preventing GSDIV infection by commercial vaccine (Biken, Japan) (Mahardika et al., 2008). However, the price of the vaccine is very expensive which is imported from Japan. Vaccinations using inactivated GSDIV virus which isolated from diseased fish organs or virus resulting from proliferation in cultured Grunt Fin (GF) cells have been successful in reducing the mortality of grouper to GSDIV viral infections in a laboratory (Mahardika et al., 2010; unpublished data). However, the crude GSDIV virus from 
diseased fish organs are not reliable continuously in large quantities and or GSDIV virus cannot develop optimally on GF cells characterized by the virus titer that is still very unstable. Therefore, it is required to apply recombinant technology methods for mass supply of GSDIV vaccine.

Production of vaccine is currently supported by the technology of recombinant proteins, by inserting the virus genes to be expressed in the host cell. This technology provides several advantages i.e. it does not require viral culture, the possibility to select specific proteins, and economiccally of mass-scale production. Institute for Mariculture Research and Development (IMRAD), Gondol was obtained a DNA library GSDIV capsid protein gene, and constructed this gene to the expression vector. The targetted gene was chosen based on previous study that the MCP gene is conserved region and plays a role in pathogenicity of the megalocytivirus virus (Sudthongkong et al., 2002b; Shimmoto et al., 2010). The aim of this study was to produce a recombinant capsid protein GSDIV and its protection to humpback grouper against GSDIV infection.

\section{MATERIALS AND METHODS}

\section{E. coli Strain, Virus Stock and DNA Preparation}

Escherichia coli strains MACH1 ${ }^{\mathrm{TM}}$-T1R and BL21(DE3) were obtained commercially (Invitrogen, Cat. No. C8620-03 and C6000-03). The pET SUMO vector (Invitrogen, Lot. no. 841075) has been described previously (Lee et al., 2008). E. coli manipulations were performed according to the manufacturers instructions. The standard DNA and protein analysis were carried out as described by Sambrook et al. (1989).

The virus was obtained from the spleen and kidneys of naturally infected fish. Spleen and kidneys were homogenized in nine times of the volume of EMEM-2 and centrifuged at 3,000 rpm for $15 \mathrm{~min}$ utes. The supernatant was filtered at $0.45 \mathrm{im}^{2}$. The filtrate is stored in $-80^{\circ} \mathrm{C}$ and used as a source of the DNA template, vaccine trials, and propagation of the virus in healthy fish.

\section{Construction of Bacterial Expression Vector}

Viral DNA was extracted from the virus pellet using a lysis buffer according to the protocol (IQ2000 ${ }^{\mathrm{TM}}$ kit). Amplification of genomic DNA using Go Taq PCR Core System I kit (Promega, Cat. M7660) with the primer design of DNA sequences capsid protein MCP RSIV (AB666334.1) with sequences 5 'ATGTCTGMRATCTCAGGTGCRAACG'3 (MCPBP), and 5' TTACAGGATAGGGAAGCCTGCAGCG '3 (MCPFP) with a weight of 1,362 bp. The MCP gene amplifica- tion was carried out in 30 cycles (denaturation temperature of $94^{\circ} \mathrm{C}$ for 1 minute, annealing temperature of $55^{\circ} \mathrm{C}$ for 1 minute and extension temperature of $72^{\circ} \mathrm{C}$ for 1 minute for one cycle), followed by denaturation temperature of $94^{\circ} \mathrm{C}$ for 1 minute and $72^{\circ} \mathrm{C}$ during the final extention for 7 minutes, and the cooling temperature of $4^{\circ} \mathrm{C}$ for 5 minutes. The resulting amplicons were visualized in agarose gel $1.5 \%$ in TAE $1 \mathrm{x}$.

PCR product was purified using a PCR purification kit (Roche, Cat. No. 11732668001) and visualized in agarose gel ( $1.5 \%$ in TAE $1 \mathrm{x})$ to get a purify and single band. The purificated DNA was then ligated to the vector $\mathrm{pET}$ SUMO (Champion ${ }^{\mathrm{TM}}$ pET SUMO, Invitrogen) according to the protocol, briefly $2 \mathrm{~mL}$ of PCR product was mixed with $1 \mathrm{~mL}$ of $10 \mathrm{x}$ ligase buffer, $2 \mathrm{~mL}$ of vector pET SUMO, $1 \mathrm{~mL}$ of T4 DNA ligase and sterile water to a total volume of $10 \mathrm{~mL}$, and then incubated at $15^{\circ} \mathrm{C}$ overnight. The ligation product was transformed in bacteria Eschericia coli strain Mach $1^{\mathrm{TM}}-\mathrm{T} 1 \mathrm{R}$.

The process of transformation was done by heatshock method, i.e. incubating $2 \mathrm{~mL}$ of mixture ligation and $50 \mathrm{~mL}$ of competent cells in crushed ice for 20 minutes, then heated in a water bath temperature of $42^{\circ} \mathrm{C}$ for 40 seconds and then quickly moved in ice to be added to $250 \mathrm{~mL}$ of growth medium SOC (super optimal catabolite expression). The transformation solution was grown for 1 hour at $37^{\circ} \mathrm{C}$ with a speed of $200 \mathrm{rpm}$ in automatic incubator shaker. Result of the growth of these cells was cultured in LB agar medium containing kanamycin $50 \mathrm{mg} / \mathrm{mL}$. Subsequently, any colonies that grew were taken to be grown in $10 \mathrm{ml}$ LB broth media containing kanamycin $50 \mathrm{mg} / \mathrm{mL}$. As a stock, a total of $0.85 \mathrm{~mL}$ of LB broth containing bacteria was mixed with $0.15 \mathrm{~mL}$ of sterile glycerin and stored at $-80^{\circ} \mathrm{C}$. Colonies that can grow in LB broth containing kanamycin $50 \mathrm{mg} / \mathrm{mL}$ indicated that the competent cells carrying a recombinant plasmid. To determine the orientation of insertion of the targetted gene was done by PCR and gene sequence analysis. The recombinant plasmid was extracted using a plasmid minispin prepease kit (USB, Lot. 1104/001). The PCR amplification to determine the orientation of the insertion of genes MCP (SUMO primer pairs forward and MCPBP) was conducted in 30 cycles (denaturation temperature of $94^{\circ} \mathrm{C}$ for 1 min., annealing temperature of $55^{\circ} \mathrm{C}$ for $1 \mathrm{~min}$. and extension temperature of $72^{\circ} \mathrm{C}$ for $1 \mathrm{~min}$. for one cycle), continued to the denaturation temperature of $94^{\circ} \mathrm{C}$ for $1 \mathrm{~min}$, and a final extension of $72^{\circ} \mathrm{C}$ for 7 min., followed by storage temperature of $4^{\circ} \mathrm{C}$ for 5 min. The correct orientation will result in DNA amplicon size of 1,465 bp (according to criteria in pET SUMO kit). 


\section{Protein Expression}

Plasmid which has been known to carry the targetted gene with the correct orientation was then transformed into competent cells of $E$. coli strain BL21. Transformation by heat-shock method was performed by incubating the recombinant plasmid and $50 \mathrm{~mL}$ BL21 in crushed ice for 30 minutes, then heated in a water bath with temperature of $42^{\circ} \mathrm{C}$ for $40 \mathrm{sec}$. and quickly moved into the ice to be added to 250 $\mathrm{mL}$ of SOC growth medium. Result of the transformation was grown for 1 hour at $37^{\circ} \mathrm{C}$ with a speed of $200 \mathrm{rpm}$. Transformant was grown in LB agar medium containing kanamycin. Any colonies that grew were cultured in $10 \mathrm{~mL}$ of LB broth media containing kanamycin for the purpose of analysis and stock.

Expression of the protein was done by inducing BL21 culture that has reached the density of $10^{8} \mathrm{cfu} /$ $\mathrm{mL}$ which determined by the absorbance value at $\mathrm{OD}_{600}$ to 1.5. A total of $10 \mu \mathrm{L}$ stock BL21 cultures were grown in $70 \mathrm{~mL}$ of LB broth containing kanamycin of $50 \mathrm{mg} / \mathrm{mL}$ with shaking of $125 \mathrm{rpm}$ at $37^{\circ} \mathrm{C}$. Sufficient density was achieved after 48 hours. Then, $0.1 \mathrm{mM}$ of IPTG was added into cultured BL21 to induce protein. Induction conducted overnight. Induction results were divided into $20 \mathrm{~mL}$ and $50 \mathrm{~mL}$ to protein analysis and used to crude inactivated subunit vaccine.

The presence of protein expression in BL21 was confirmed by SDS-page. A total of $20 \mathrm{~mL}$ cultured BL21 that had been induced with IPTG was centrifuged at 6,000 rpm for $10 \mathrm{~min}$. Pellets were then lyzed enzymatically with lysozyme and mechanically with freeze-thawing method and sonication. Enzymatic lysis was performed by incubating $100 \mu \mathrm{L}$ of pellet with $150 \mu \mathrm{L}$ of $200 \mathrm{mM}$ lysozyme at $37^{\circ} \mathrm{C}$ for $5 \mathrm{~min}$. Then, these cells were lyzed with freeze-thawing and sonication (freeze at $-80^{\circ} \mathrm{C}$ and melt at a temperature of $42^{\circ} \mathrm{C}$ for 30 times, and then sonicated for $4 \times 15$ minutes). The cell solution was centrifuged at maximum speed for $1 \mathrm{~min}$. A $10 \mu \mathrm{L}$ of pellet and $25 \mu \mathrm{L}$ of supernatant were taken for the SDS-page analysis.

SDS-page sample was prepared by adding $1 \mathrm{x}$ sample buffer $(1.25 \mathrm{~mL}$ of $0.5 \mathrm{M}$ Tris-CL pH $6.8,1 \mathrm{~mL}$ of $100 \%$ glycerol, $0.2 \mathrm{~mL}$ of beta-merkaptoethanol, $0.01 \mathrm{~g}$ bromo phenol blue, $2 \mathrm{~g}$ SDS, and sterile distilled water to a total volume of $10 \mathrm{~mL}$ ) into pellet and $2 \mathrm{x}$ sample buffer into the supernatant with an equivalent volume. The mixture solution was heated in boiling water for $5 \mathrm{~min}$. and cooled at room temperature. The sample was then injected into $12 \%$ of porous gel poliacrylamyde that had been prepared. On one hole of gel was injected with 10-200 kDa protein marker (Bio Basic Inc., Lot. 1203SH00072277R2) to determine the molecular weight of the protein. Elec- trophoresis was performed in a buffer containing glycine for $45 \mathrm{~min}$. at a voltage of 200 volts. Gel electrophoresis was stained with comassie brilliant blue (CBB) for one hour. The excess of gel color was reduced by soaking in the decolorizer solution $(7 \mathrm{~mL}$ of glacial acetic acid, $7 \mathrm{~mL}$ methanol, and $86 \mathrm{~mL}$ of distilled water) for $30 \mathrm{~min}$. with a shaker and subsequently allowed to stand until one night.

\section{DNA Sequense Analysis}

DNA sequencing was conducted to determine the DNA sequence of the gene MCP-GSDIV virus. The samples used were the result of amplification of vectors that have been inserted by MCP gene in the correct orientation. PCR product was then purified by PCR purification kit (Roche). Samples were sequenced using the services of $1 \mathrm{st}$ BASE provider (Singapore). DNA sequences were analyzed by BLAST to know its homology, and ORF Finder for prediction of nucleotide acids.

\section{Protein Analysis}

The function of the target gene in expressing the protein was confirmed by sequenzed of protein production. The sample used for the sequencing was a piece of band in gel electrophoresis-polyacrilamide that showed over-expression. Protein sequencing through a service provider (proteomics International Pty Ltd, Australia) which uses the technique of protein digestion with trypsin, and the resulting peptides were analyzed by MALDI TOF-TOF (matrix-assisted laser desorption/ionization mass spectrometry time of flight-time of flight) tandem mass spectrophotometer (4,800 proteomics analyzer, AB Sciex). Protein identification using Mascot software based on data Ludwig NR. Results obtained from the provider reanalyzed by BLAST to know its homology.

\section{Crude Protein Subunit Vaccine Preparation}

A $50 \mathrm{pg} / \mathrm{mL}$ cultured of $E$. coli strain BL21 that had been induced and known to express proteins (by SDSpage) was inactivated by adding formalin to a final concentration of $0.03 \%$. Formalin inactivation was carried out for one night at room temperature. Formalin was cleared by centrifugation at $6,000 \mathrm{rpm}$ for $5 \mathrm{~min}$. and the pellet was lyzed by sonication (4 x 15 min.). The pellet was diluted into obtain the density of bacteria that was equivalent to the initial density $\left(10^{8} \mathrm{CFU} / \mathrm{mL}\right)$.

\section{Vaccination Trials}

Vaccine trials were done using juveniles of humpback grouper with total length of $6-8 \mathrm{~cm}$. The vaccine was given by intramuscular injection with a dose of $0.1 \mathrm{~mL} / \mathrm{fish}$, while control group was given PBS 
(negative control) or CAT (positive/protein control). Vaccine trials conducted in laboratory scale (15-20 fish in aquarium with volume of $100 \mathrm{~L}$ ) and a semimass scale (100 and 150 fish in a floating net at $1 \mathrm{~m} \mathrm{x}$ $1 \mathrm{~m} \times 0.75 \mathrm{~m}$, which floated in concrete tank). The vaccine is given as a single and booster with intervals of 7 days. GSDIV virus challenge test was done after 14, 20, 30 days from the last vaccination. Effectiveness of vaccine was determined by the value of the relative percentage survival (RPS) after challenged with the GSDIV virus which has a $100 \%$ lethal dose. The data of challenge test results were presented in the form of percent mortality and RPS (percent survival ratio) with the formula:

$$
\text { RPS }=\frac{(1-\% \text { mortality of treatment })}{\% \text { mortality of control }} \times 100
$$

\section{RESULTS AND DISCUSSION}

\section{Amplification of Gene Target}

Target genes which obtained from the spleen of diseased fish could be amplified with primers that were designed based on the gene RSIV (red sea bream iridovirus) in the region of the MCP. Optimization of amplification conditions could produce amplicon with the correct size of 1,362 bp (Figure 1). This result indicated the gen GSDIV in the region of the MCP have similarity with the gen RSIV. The result is resembled with a previous research which claimed that the ATPase gene and the MCP gene of SBIV (sea bass iridovirus), RSIV (red sea bream iridovirus), GSDIV (grouper sleepy disease iridovirus), ALIV (African lampeye iridovirus), and DGIV (dwarf gourami iridovirus) were highly homologous (> 95.8\%, > 94.9\% identity) (Sudthongkong et al., 2002b).

\section{Cloning and Gene Exppresion}

Some colonies of $E$. coli strain Mach1 were known to carry the recombinant plasmid with the insertion of targetted gene into the vector of pET SUMO. It was shown from the result of a target gene amplification using primer vector and primer target gene. The amplicons exhibited 150 base pairs (total 1,512 bp) longer than the target genes due to the use of primary vector (Figure 2).

Recombinant plasmid was expressed the protein in cells E. coli strain BL-21 with induction of $0.1 \mathrm{mM}$ of IPTG. Results of electrophoresis with gel SDS-page indicated that molecular weight of the recombinant MCP was $60 \mathrm{kDa}$ (Figure 3). MCP is comprised of the outer capsid proteins with a molecular weight of $50 \mathrm{kDa}$. The MCP gene sequence is conserved regions in members of family Iridovirus. It could be used in basic detection of viral particles in the family of Iridovirus (Chincar et al., 2011).

The results of proteins electrophoresis of gel polyacrylamide was known recombinant proteins (marked with thick band/over expression) parallel to the $60 \mathrm{kDa}$ (Figure 3). This was the effect of the fusion protein SUMO (small ubiquitin-like modifier). This was based on the results of the digestion of proteins from the process of protein analysis by MALDI TOF-TOF which proves that overexpression of MCP protein carrying the $12.1 \mathrm{kDa}$ of protein of Saccharomyces cerevisiae and MCP-GSDIV protein (49.566 kDa). The aim of selecting the expression plasmid with

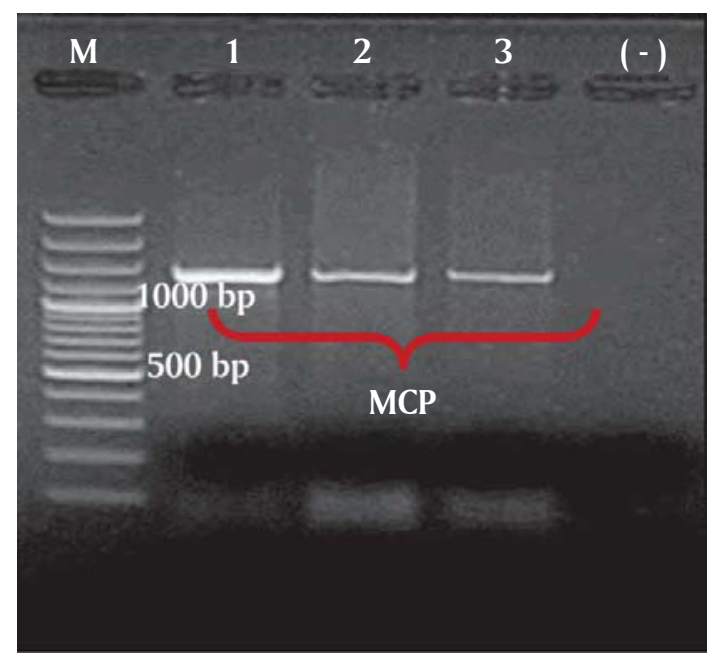

Figure 1. MCP-targetted gene in agarose gel shows the expected amplicon size (1,362 bp.). M: 100 bp DNA ladder, (-): control negative 


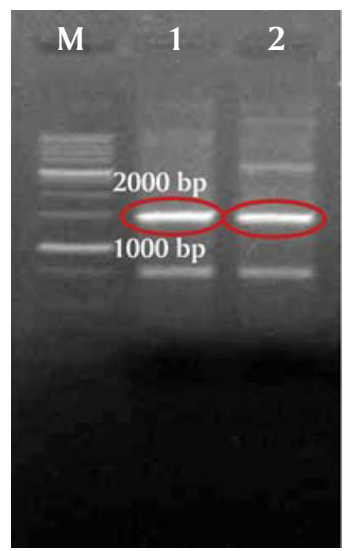

Figure 2. PCR confirmed a recombinant plasmid for correct orientation using plasmid forward primer and targetted gene backward primer. M: 100 bp DNA ladder M

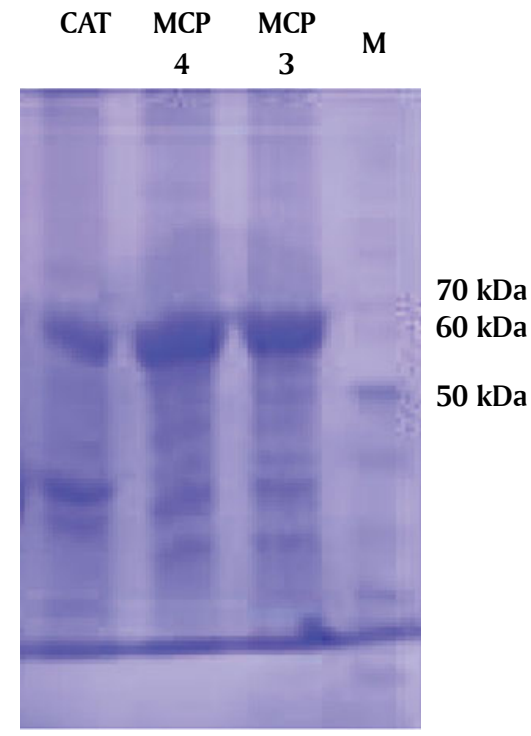

Figure 3. SDS-page gel shows protein expression of MCP gene

SUMO fusion was to improve the solubility of expressed proteins that was easy to be isolated (Der et al., 2008). Further expected protein could be obtained by partially solving of cells through sonication to be used as a crude subunit vaccine.

\section{Sequence of the DNA Gene Target}

MCP gene sequencing was obtained partial nucleotide sequences (partial cds), i.e. 1,226 of 1,362 nucleotides (Figure 4). BLAST homology analysis showed that the gene MCP-GSDIV have similarity up to $99 \%$ with the other isolates Megalocytivirus as shown in Table 1. Sequences producing significant alignments:
MCP-encoding gene was known with size of 1,362-1,372 bp and encodes 454 amino acids. The gene revealed a highly identical ( $>97.2 \%$ identity) with some isolates of Megalocityvirus namely SBIV, RSIV, GSDIV, ALIV, DGIV (Sudthongkong et al., 2002b).

\section{Sequence of Protein}

Peptide analysis with MALDI-TOF-TOF showed that recombinant MCP-GSDIV expressed a protein fusion MCP and modification protein from vector. The molecular size of MCP was $49.566 \mathrm{kDa}$ with PI value of 6.00 , while the modification protein of vector was $12.1 \mathrm{kDa}$ (Figure 5). Peptide identification based on 
Table 1. Some isolates Megalocytivirus that have similarities with gene MCP-GSDIV

\begin{tabular}{|c|c|c|c|c|c|c|}
\hline Accession & Description & $\begin{array}{c}\text { Maxima } \\
\text { score }\end{array}$ & $-\frac{\text { Total }}{\text { score }}$ & $\begin{array}{l}\text { Query } \\
\text { coverage }\end{array}$ & E value & $\underline{\text { Max }}$ \\
\hline LQ253372.1 & $\begin{array}{l}\text { Megalocytivirus Sabah/RAA/2012 strain OSGIV75 } \\
\text { major capsid protein gene, complete cds }\end{array}$ & $\underline{2254}$ & 2254 & $99 \%$ & 0.0 & $99 \%$ \\
\hline$\underline{\mathrm{HQ} 317465.1}$ & $\begin{array}{l}\text { Infectious spleen and kidney necrosis virus isolate ISKNV-DW } \\
\text { major capsid protein (mcp) gene, complete cds }\end{array}$ & $\underline{2254}$ & 2254 & $99 \%$ & 0.0 & $99 \%$ \\
\hline AF371960.1 & Infectious spleen and kidney necrosis virus, complete genome & $\underline{2254}$ & 2254 & $99 \%$ & 0.0 & $99 \%$ \\
\hline AY285745.1 & African lampeye iridovirus major capsid protein gene, complete cds & $\underline{2248}$ & 2248 & $99 \%$ & 0.0 & $99 \%$ \\
\hline$\underline{\mathrm{AB} 109369.1}$ & Dwarf gourami iridovirus gene for major capsid protein, complete cds & $\underline{2231}$ & 2231 & $99 \%$ & 0.0 & $99 \%$ \\
\hline
\end{tabular}

11 gggtttatcga

22 atctccgcgtttgatgcgatggagacccacttgtacggcggcgac $\begin{array}{llllllllllllllll}\text { I } & S & A & F & D & A & M & E & \text { T } & \text { H } & \text { L } & \text { Y } & G & G & D\end{array}$

67 aatgccgtgacctactttgcccgtgagaccgtgcgtagttcctgg $\begin{array}{lllllllllllllll}N & A & V & T & Y & F & A & R & E & T & V & R & S & S & W\end{array}$

112 tacagcaaactgccegtcaccetgtcaaaacagactggccatgcc $\begin{array}{llllllllllllllll}Y & S & K & L & P & V & T & L & S & K & Q & T & G & H & A\end{array}$

157 aattttgggcaggagtttagtgtgacggtggcgaggggcggcgac

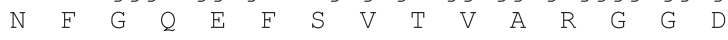

202 tacctcattaatgtgtggctgcgtgttaagatcccctccatcaca $\begin{array}{llllllllllllllll}Y & L & I & N & V & W & \text { L } & R & V & K & I & P & S & I & T\end{array}$

247 tccagcaaggagaacagctacatccgctggtgcgacaatctgatg $\begin{array}{llllllllllllllll}S & S & K & E & N & S & Y & I & R & W & C & D & N & L & M\end{array}$

292 cacaatctagtggaggaggtgtcggtgtcatttaacgacctggtg $\begin{array}{lllllllllllllll}H & N & L & V & E & E & V & S & V & S & F & N & D & L & V\end{array}$

337 gcacagaccctcaccagcgagttccttgacttctggaacgcctgc $\begin{array}{llllllllllllllllll}A & Q & T & L & T & S & E & F & L & D & F & W & N & A & C\end{array}$

382 atgatgcccggcagcaaacagtctggctacaacaagatgattggc $\begin{array}{llllllllllllllllllllll}M & M & P & G & S & K & Q & S & G & Y & N & K & M & I & G\end{array}$

427 atgcgcagcgacctggtggccggcatcaccaacggccagactatg $\begin{array}{lllllllllllllll}M & R & S & D & L & V & A & G & I & T & N & G & Q & T & M\end{array}$

472 cccgccgtctaccttaatttgcccattcccetcttcttacccgt $\begin{array}{lllllllllllllll}P & A & V & Y & L & N & L & P & I & P & L & F & F & T & R\end{array}$

517 gacacgggcctggcgttgcctaccgtgtctctgccgtacaacgag

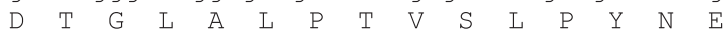

562 gtgcgcatccacttcaagctgcggcgctgggaggacctgctcatc $\begin{array}{llllllllllllllll}V & R & I & H & F & K & L & R & R & W & E & D & L & L & I\end{array}$

607 agccagagcaaccaggccgacatggccatatcgaccgtcaccctg $\begin{array}{lllllllllllllll}S & Q & S & N & Q & A & D & M & A & I & S & T & V & T & L\end{array}$

652 gctaacattggcaatgtagcacccgcactgaccaatgtgtctgtg $\begin{array}{lllllllllllllll}A & N & I & G & N & V & A & P & A & L & T & N & V & S & V\end{array}$

697 atgggcacttacgctgtactgacaagcgaggagcgtgaggtggtg $\begin{array}{lllllllllllllllll}M & G & T & Y & A & V & L & T & S & E & E & R & E & V & V\end{array}$

742 gcccagtctagtcgtagcatgctcattgaacagtgccaggtggcg $\begin{array}{llllllllllllllllllllll}A & Q & S & S & R & S & M & L & I & E & Q & C & Q & V & A\end{array}$

787 cccegtgtgcccgtcacgcccgcagacaattcttggtgcatctg $\begin{array}{llllllllllllllll}P & R & V & P & V & T & P & A & D & N & S & L & V & H & L\end{array}$

832 gacctcaggttcagtcaccccgtgaaggccttgttctttgcagta

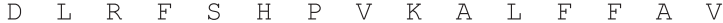

877 aagaacgtcacccaccgcaacgtgcaaagcaactacaccgcggcc $\begin{array}{lllllllllllllllll}K & N & V & T & H & R & N & V & Q & S & N & Y & T & A & A\end{array}$

922 agtcccgtgtatgtcaacaacaaggtgaatctgccattgatggcc $\begin{array}{lllllllllllllll}S & P & V & Y & V & N & N & K & V & N & \text { L } & \text { P } & \text { L } & \text { M } & \text { A }\end{array}$

967 accaatcccetgtccgaggtgtcactcatttacgagaacacccct $\begin{array}{lllllllllllllll}T & N & P & L & S & E & V & S & L & I & Y & E & N & T & P\end{array}$

1012 cggctccaccagatgggagtagactacttcacatctgtcgacccc $\begin{array}{lllllllllllllll}R & L & H & Q & M & G & V & D & Y & F & T & S & V & D & P\end{array}$

1057 tactactttgcgcccagcatgcctgaaatggatggtgttatgacc $\begin{array}{llllllllllllllllllll}Y & Y & F & A & P & S & M & P & E & M & D & G & V & M & T\end{array}$

1102 tactgctatacgttggacatgggcaatatcaaccccatgggttca $\begin{array}{llllllllllllllllllllll}Y & C & Y & T & L & D & M & G & N & I & N & P & M & G & S\end{array}$

1147 accaactacggccgcctgtccaacgtcccctggcatgtaagggg $\begin{array}{llllllllllllllll}T & N & Y & G & R & L & S & N & V & P & \text { L } & A & C & K & G\end{array}$

1192 tcggacaatgcaaagaccaccceggcgggcgggggcggcaacggc $\begin{array}{llllllllllllllll}S & D & N & A & K & T & T & P & A & G & G & G & G & N & G\end{array}$

1237 tccggtacacggtggcccaa $\begin{array}{lllllllll}S & G & T & R & \text { W } & & & & \end{array}$

Figure 4. Partial coding sequence (partial cds) of gene encoding MCP-GSDIV 
the its spectra showed that MCP was completely expressed and the peptide sequence of MCP was similar to MCP has MCP-LYCIV (large yellow croake iridivirus) and MCP-GSIV (giant Seaperch iridovirus). This was supported by the results of BLAST analysis that showed $99 \%$ similarity with MCP of red sea bream iridovirus (gi | 29,467,056 | BAC66968.1), MCP-infectious spleen and kidney necrosis virus (gi | 315 454520 | ADU25248.1), MCP-grouper sleepy disease iridovirus (gi | 30,909,113 | AAP37443.1), MCP-infectious spleen and kidney necrosis virus (gi | 57,233,193 | AAW48183.1).

MCP gene was expressed completely, producing peptides with amino acid number of 453 . The amino acid sequence was similar to the MCP-RSIV (gi | 29,467,056 | BAC66968.1). These results are resembled with MCP-Iridovirus gene sequences isolated from the South China Sea and South East Asian countries. The MCP-Iridovirus gene consists of 1,362 and 1,372 base pairs and encodes a 454 amino acid (Sudthongkong et al., 2002b). The analysis of the nucleotide and amino acid sequences had visible result of mutual support. Therefore, it can be concluded that the targetted gene expressed the expected protein.

\section{Vaccination Test on Humbuck Grouper}

Vaccine indicated that the MCP gene was potential to induce fish immunity against GSDIV. In a laboratory scale test (Table 2 ) with challenged by isolates GSDIV that has a $100 \%$ lethal dose, a crude subunit vaccine resulted a value of RPS to $54.58 \%$. In a semimass scale test (Table 3), GSDIV infection does not occur naturally, thus, GSDIV infection was done experimentally at 20 fish. Results of the challenge test showed that the crude subunit vaccine achieved RPS value of $100 \%$ during the 21 days post final vaccination. However, the RPS values decreased after 30 days post final vaccination. This condition was worsened by a bacterial infection that causes tail root (Figure $6)$. The effects of booster vaccine with an interval of 7 days from the initial vaccine has not shown an increase in the value of RPS after challenge with the virus GSDIV after 30 days post booster vaccine.

The vaccinated fish showed different growth during the vaccination period. All groups were assumed to have same initial weight $(8.86 \mathrm{~g})$. The fish vaccinated by the crude subunit vaccine indicated the best growth rate with the average weight of $29.2 \mathrm{~g}$ and

\begin{tabular}{|c|c|c|c|}
\hline Query & 1 & $\begin{array}{l}\text { MSAISGANVTSGF IDISAFDAMETHLYGGDNAVTYFARETVRSSWYSKLPVTLSKQTGHA } \\
\text { MSAISGANVTSGFIDISAFDAMETHLYGGDNAVTYFARETVRSSWYSKLPVTLSKQTGHA }\end{array}$ & 50 \\
\hline Sbjet & 1 & MSAISGANVTSGFIDI SAFDAMETHLYGGDNAVTYFARETVRSSWYSKLPVTLSKQTGHA & \\
\hline Query & 61 & $\begin{array}{l}\text { NFGQEFSVTVARGGDY LINVWLRVKI PS ITSSKENSYIRWCDNLMHNLVEEVSVSFNDLV } \\
\text { NFGQEFSVTVARGGDYLINVWLRVKIPSITSSKENSYIRWCDNLMHNLVEEVSVSFNDLV }\end{array}$ & \\
\hline Sbjet & 61 & NFGQEFSVTVARGGDYLINVWLRVKI PS ITSSKENSYIRWCDNLMHNLVEEVSVSFNDLV & \\
\hline Query & 121 & AQTLTSEFLDFWNACMMPGSKQSGYNKMI GMRSDLVGGITNGQTMPAAYLNLPI PLEFTR & \\
\hline Sbjet & 121 & $\begin{array}{l}\text { AQTLTSEFLDFWNACMMPGSKQSGYNKMI GMRSDLVGGI TNGQTMPAAYLNLPI PLFFTR } \\
\text { AQTLTSEFLDFWNACMMPGSKQSGYNKMI GMRSDLVGGITNGQTMPAAYLNLPIPLFFTR }\end{array}$ & \\
\hline Query & 181 & $\begin{array}{l}\text { DTGLALPTVSLPYNEVRI HFKLRRWEDLLISQSTQADMA IS TVTVANIGNVTPALTNVSV } \\
\text { DTGLALPTVSLPYNEVRI HFKLRRWEDLLISQSTQADMA ISTVTVANIGNVTPALTNVSV }\end{array}$ & \\
\hline Sbjet & 181 & DTGLALPTVSLPYNEVRI HFKLRRWEDLLISQSTQADMA ISTVTVANIGNVTPALTNVSV & \\
\hline Query & 241 & $\begin{array}{l}\text { MGTYAVLTSEEREVVAQSSRSMLIEQCQVAPRVPVTPVDNSLVHLDLRFSHPVKALFFAV } \\
\text { MGTYAVLTSEEREVVAQSSRSMLIEQCQVAPRVPVTPVDNSLVHLDLRFSHPVKALFFAV }\end{array}$ & \\
\hline Sbjet & 241 & MGTYAVLTSEEREVVAQSSRSMLIEQCQVAPRVPVTPVDNSLVHLDLRFSHPVKALFFAV & \\
\hline Query & 301 & $\begin{array}{l}\text { KNVTHRNVQSNYTAAS PVYVNNKVNL PLLATNPLSEVSL IYENT PRLHQMGVDYFTSVDP } \\
\text { KNVTHRNVQSNYTAAS PVYVNNKVNLPLLATNPLSEVSLIYENTPRLHQMGVDYFTSVDP }\end{array}$ & \\
\hline Sbjet & 301 & KNVTHRNVQSNYTAAS PVYVNNKVNLPLLATNPLSEVSLIYENT PRLHQMGVDYFTSVDP & \\
\hline Query & 361 & $\begin{array}{l}\text { YYFAPSMPEMDGVMTYCYTLDMGN INFMGSTNYGRLSNVTLSCKVSDNakttaaggggng } \\
\text { YYFAPSMPEMDGVMTYCYTLDMGN INFMGSTNYGRLSNVTLSCKVSDNAKTTAAGGGGNG }\end{array}$ & \\
\hline Sbjet & 361 & YYFAPSMPEMDGVMTYCYTLDMGN INFMGSTNYGRLSNVTLSCKVSDNAKTTAAGGGGNG & \\
\hline Query & 421 & $\begin{array}{l}\text { tgytVaQKFELVVIAVNHNIMKIADGAAGFPIL } 453 \\
\text { TGYTVAQKFELVVIAVNHNIMKIADGAAGFPIL }\end{array}$ & \\
\hline & 421 & TGYTVAQKFELVVIAVNHNIMKIADGAAGFPIL & \\
\hline
\end{tabular}

Figure 5. Amino acid sequence alligment with other highly homolog MCP Megalocityvirus 

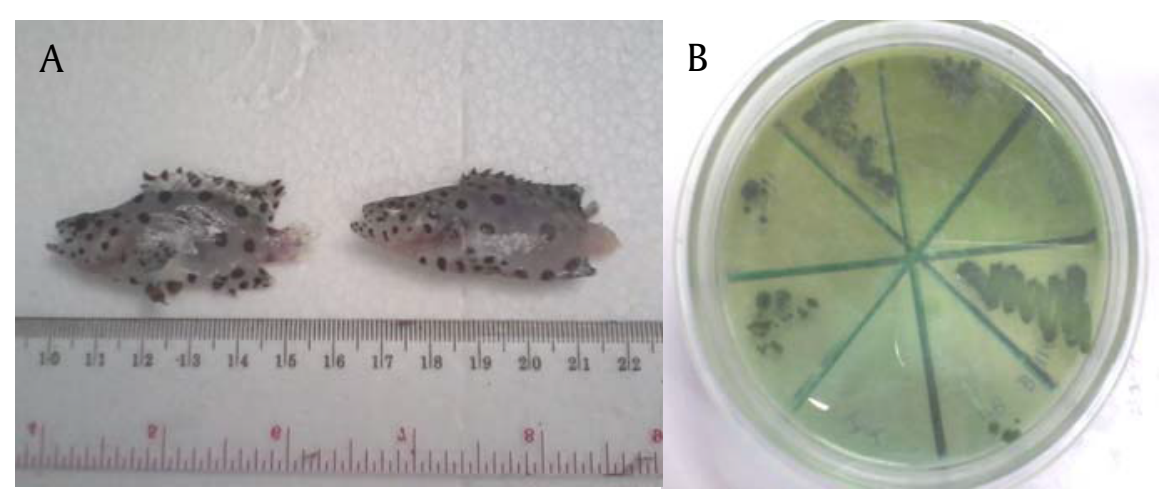

Figure 6. Bacterial infection within challenge test period at 30 day post final vaccination experiment, Bacterial infection caused fin root disease (A); bacteria grew on TCBSA (B)

Table 2. RPS value of the crude subunit vaccine at laboratory experimental scale

\begin{tabular}{lcccccc}
\hline \multirow{2}{*}{ Treatments } & \multicolumn{2}{c}{$\begin{array}{c}\text { 14 Days post final } \\
\text { vaccination }\end{array}$} & & \multicolumn{2}{c}{$\begin{array}{c}\text { 21 Days post final } \\
\text { vaccination }\end{array}$} \\
\cline { 2 - 3 } \cline { 6 - 7 } & \multicolumn{2}{c}{ Mortality (\%) } & RPS (\%) & & Mortality (\%) & RPS (\%) \\
\hline MCP 1 & 40.87 & 54.58 & & 75.66 & 24.44 \\
CAT (+ control) & 90 & 0 & & 100 & 0,00 \\
PBS (- control) & 90 & - & & 100 & - \\
\hline
\end{tabular}

Table 3. RPS value of the crude subunit vaccine at semi-mass experimental scale

\begin{tabular}{|c|c|c|c|c|c|c|c|c|c|}
\hline \multirow{3}{*}{ Trial } & \multirow{3}{*}{ Treatments } & \multirow{2}{*}{\multicolumn{2}{|c|}{$\begin{array}{c}\begin{array}{c}\text { Days after fin } \\
\text { root infection }\end{array} \\
\text { Until } 22 \text { days }\end{array}$}} & \multicolumn{6}{|c|}{ Days post final vaccination } \\
\hline & & & & \multicolumn{2}{|c|}{14 days } & \multicolumn{2}{|c|}{20 days } & \multicolumn{2}{|c|}{30 days } \\
\hline & & Mortality (\%) & RPS (\%) & Mortality (\%) & RPS (\%) & Mortality (\%) & RPS (\%) & Mortality (\%) & RPS (\%) \\
\hline \multirow[t]{2}{*}{1} & MCP & - & - & - & - & 0 & 100 & 66.7 & 31 \\
\hline & $\begin{array}{l}\text { CAT (positive/ } \\
\text { protein control) }\end{array}$ & - & - & - & - & 15 & 0 & 96.7 & 0 \\
\hline \multirow[t]{2}{*}{2} & MCP & 39.2 & 15 & 40 & 56 & 75 & 16.7 & 80 & 7,7 \\
\hline & PBS (negative control) & 46 & 0 & 90 & 0 & 90 & 0 & 86.7 & 0 \\
\hline
\end{tabular}

$29.0 \mathrm{~g}$ at the end of the vaccination period. This value is higher than those of the control group which was injected by the crude protein SUMO CAT vaccine i.e. $26.7 \%$.

Some isolates of Megalocityvirus have been known as a complete genome such as ISKNV (AF371960), RSIV-Ehime1 strain (BD143114, AB104413), rock bream iridovirus (RBIV) (AY532606), orange-spotted grouper iridovirus (OSGIV) (AY894343), TRBIV (GQ273492) and large yellow croaker iridovirus (LYCIV)
(AY779031). Based on the complete genome, structure of MCP RSIV-Ehime strain was known to be the genes that are common to Megalocityvirus (Kurita \& Nakajima, 2012). Some capsid protein encoding ORF on Megalocytivirus genome have been developed as a vaccine, such as ORF and ORF 7L $11 \mathrm{~L}$ which are the gene encoding the structural proteins of the capsid Megalocytivirus (Lua et al., 2005). Instead of MCP has been used as a recombinant protein vaccine (Shimmoto et al., 2010). 
This study utilised a crude subunit MCP protein vaccine which was expected to modulate specific immune system controlled by recombinant MCP protein, and non-specific immune system of fish conducting by owned bacteria protein, supported by the research result of Shimmoto et al. (2010). MCP vaccine has the potential to induce specific immune system that reflected by the value of the RPS. In another study, the increase in specific immunity was also achieved when the recombinant RSIV vaccine was used to alleviate RSIV infection, signified by the increase in serum antibody and expression of MHC class 1 which is display intracellular proteins to cytotoxic $T$ cells (CTLs), and also present peptides generated from exogenous proteins (Caipang et al., 2006).

Results of the vaccination in the laboratory scale and or semi-mass scale showed a good protective effect in 14 days post vaccination. However, this good protective effect started to decline at days of 20-21. This result suggested that the protection period of the vaccination using subunit MCP protein vaccine by single or double (booster) apllication with an interval of 7 days are still short. Therefore, it is required to apply booster vaccine at 14-20 days after the first vaccination. This booster vaccine is intended to maintain high immunity level after 14 days post vaccination. In addition, Adjuvants could also be added to the vaccine to improve the efficacy and stability of the vaccine formulations to give a longer period of protection. Further research needs to be done to improve the protection period by addition of adjuvants.

\section{CONCLUSION}

GSDIV gene encoding region of the MCP had successfully cloned into the expression plasmid. MCP gene was well expressed and the corresponding protein was obtained. Application of recombinant proteins as a crude subunit vaccine was potential to induce the immune system that reflected by the RPS value, although it provides short protection period (14-20 days).

\section{ACKNOWLEDGEMENT}

Authors would like to thank Prof. Dr. I Gusti Ngurah Kade Mahardika (Biomedic and Molecular Biology of Veterinary Lab., Faculty of Veterinary, University of Udayana), Prof. Dr. Haryanti (Biotechnology Lab., IMRAD), and Dr. Hendro Pramono, M.Sc. (Faculty of Biology, University of Jenderal Soedirman) for their guidance and advice given. The authors also wish to thank my fellow colleagues as technician at Laboratory of Biotechnology, IMRAD who helped in the research activities.

\section{REFERENCES}

Caipang, C.M.A., Takano, T., Hirono, I., \& Aoki, T. (2006). Genetic vaccine protect red sea bream iridovirus, Pagrus major, upon challenge with Red Sea Bream Iridovirus (RSIV). Fish and Shellfish Immunology, 21, 130-138.

Chincar, V.G., Yu, K.H. \& Jancovich, J.K. (2011). The molecular biology of frog virus 3 and other iridoviruses infecting cold blooded vertebrates. Viruses, 3, 1059-1985.

Der Lee, C., Hui-Chien, S., Su-Ming, H., Ching-Feng, C., Atthachai, H., Shu-Mei, L., \& Chih-Hsiang, L. (2008). An improved sumo fusion protein system for effective production of native proteins. Protein Science, 17, 1241-1248.

Koesharyani, I., Roza, D., Mahardika, K., Johnny, F., Zafran, \& Yuasa, K. (2001). Iridovirus. In Sugama, K., Ikenoue, H., \& Kawahara, S (Eds.). Manual for fish disease diagnosis-II. Marine fish and crustacean diseases in Indonesia. Gondol Marine Research for Mariculture, Central Research Institute for Sea Exploration and Fisheries, Dep of Marine Affair and Fisheries, and Japan International Cooperation Agency, p. 5-7.

Kurita, J., \& Nakajima, K. (2012). Megalocityviruses (Reviev). Viruses, 4, 521-538.

Lua, W., Yasuike, J., Hirono, I., \& Aoki, T. (2005). Transcription program of red sea bream iridovirus as revealed by DNA microarrays. J. Virol., 79, 15151-64.

Mahardika, K., Koesharyani, I., Sugama, K., Priyono, A., \& Yuasa, K. (2001) Histopathological study of iridovirus infection in Epinephelus coioides and Epinephelus bleekeri. Proceedings of Mariculture Technology and Sea Farming Development. Jakarta, Indonesia - Japan International Cooperation Agency. Jakarta, p. 334-341 (in Indonesian with English abstract).

Mahardika, K., Koesharyani, I., Prijono, A., \& Yuasa, K. (2003). Iridovirus infection in broodstock of orange-spotted grouper (Epinephelus coioides). J. Pen. Perik. Indonesia, 9(1), 11-15 (in Indonesian with English abstract).

Mahardika, K., Zafran, Roza, D., \& Johnny, F. (2004). Susceptibility of orange-spotted grouper, Epinephelus coioides and marbled grouper, Epinephelus microdon to iridovirus infection. Indonesian Aquaculture Journal, 10(2), 83-88 (in Indonesian with English abstrack).

Mahardika, K., Haryanti, Muzaki, A., \& Miyazaki, T. (2008). Histopathological and ultrastructural features of enlarged cells of humpback grouper Cromileptes altivelis challenged with Megalocytivirus (Family Iridoviridae) after vaccination. Dis. Aquat. Org., 79, 163-168. 
Mahardika, K., \& Miyazaki, T. (2009). Electron microscopic features of cultured grunt fin cells infected with Megalocytivirus. Aquaculture Sciences, 57, 9-18.

Mahardika, K., \& Mastuti, I. (2010). Iridovirus infection (Sea Bass Iridovirus, Genus: Megalocityvirus) in sea bass Lates calcarifer and its pathogenicity to the humpback grouper Cromileptes altivelis. Prosiding Seminar Nasional Perikanan Indonesia. p. 167-173 (in Indonesian with English abstrack).

Nakajima, K., Maeno, Y., Kurita, J., \& Inui, Y. (1997). Vaccination against red sea bream iridoviral disease in red sea bream. Fish Pathol., 32, 205-209.

Nakajima, K., Maeno, Y., Honda, A., Yokoyama, K., Tooriyama, T., \& Manabe, S. (1999). Effectiveness of a vaccine against red sea bream iridovirus disease in a field trial test. Disease Aquatic Organisms, $36,73-75$.
Sambrook, J., Fritsch, E.F., \& Maniatis, T. (1989). Molecular cloning: a laboratory manual. 2nd edn. Cold Spring Harbor Laboratory Press, Cold Spring Harbor, NY.

Shimmoto, H., Kawai, K., Ikawa, T., \& Oshima, S-I. (2010). Protection of red sea bream Pagrus major against red sea bream iridovirus infection by vaccination with a recombinant viral protein. Microbiol. Immunol., 54, 135-142.

Sudthongkong, C., Miyata, M., \& Miyazaki, T. (2002a). Iridovirus disease in two ornamental tropical freshwater fishes: African lampeye and dwarf gourami. Dis. Aquat. Org., 48, 163-173.

Sudthongkong, C., Miyata, M., \& Miyazaki, T. (2002b). Viral DNA sequences of genes encoding the ATPase and the major capsid protein of tropical iridovirus isolates which are pathogenic to fishes in Japan, South China Sea and South East Asian countries. Archives Virology, 147, 2089-2109. 